American Journal of Environmental Sciences 3 (4): 199-204, 2007

ISSN 1553-345X

(C) 2007 Science Publications

\title{
Necessary Geomorphologic Information For Roads Safety, With Emphasize Soleghan Road In West Of Tehran, Iran
}

\author{
Ebrahim Moghimi \\ Geography Department, University of Tehran, Iran
}

\begin{abstract}
This paper review some of the aspects of necessary disciplines of geomorphology and roads, with emphasize Soleghan road. For building this road didn't consider geomorphology process carefully. so the safety rang of the road is low and with consider to increasing traffic, the rang of danger is high. Specific subjects are related to the description of slops phenomena, including rock fall, block slide, rock creep, talus creep, debris flow, rock avalanches and floods. The river process, sloop steep, joint and fault system are the most important geomorphologic information of the Soleghan road. Soleghan road have been studied in this view and thus provide information which take the basis of stability road. Every road in Iran or world can include one or some important process, so some information is needed. More than half of Iran and world roads have built about before 1970, when the geomorphologic education and research was in the early of stage. Therefore many of Iran and world roads such as Soleghan road haven't built with new geomorphologic and basic information. Too more damages which in order to geomorphologic process exposed to roads, people and cars in Iran and world such as Soleghan road are increased. Many flood and slumps destroyed built roads, many people and cars, damage or crash to ignoring the geomorphologic information, thus if we use geomorphologic information in road building, damage and crashes will be decreased, so safety will be increase.
\end{abstract}

Keywords: road, safety, geomorphology, Soleghan, information.

\section{INTRODUCTION}

Geomorphology has been defined the study of surface land forms ${ }^{[2]}$. It is proceeded to the nature, origin and evolution of landforms, their processes and promotion of their material composition ${ }^{[4}$ and 6$]$. This knowledge is predominantly a field science, and requires to aim for studying landforms, terrestrial Processes and surface materials ${ }^{[8]}$. If the aim is road policy-making, road-guarding, road-building and safety, it is proceeded to the group of effective processes on roads. All these aims require directly to the geomorphologic studies particularly in mountain areas ${ }^{[10]}$. Soleghan road have been studied in this view ${ }^{[9]}$, and thus provide information which take the basis of stability roads.

At present, Geomorphologic information has probably not been applied to the needs for Soleghan road stability. There is, however, an increasing recognition by both geomorphologies and by road policy-makers, that geomorphology has an important role in roads to play alongside other disciplines in the engineering and technical sciences ${ }^{[9,5]}$.It is necessary that the road policy-makers be aware of the geomorphologic information can provide and of how it can use in planning formulation of road. The main emphasis is on issues that dealt with road policy-making, planning ${ }^{[7]}$, land stability and safety.

The method of study comprises field and Laboratory works, field studies include selection of appropriate stations record for Soleghan road، The interpretation of aerial photography maps (1/50000), geological maps (1/100000), and using of Arc-GIS and Land set images(Fig. 1).

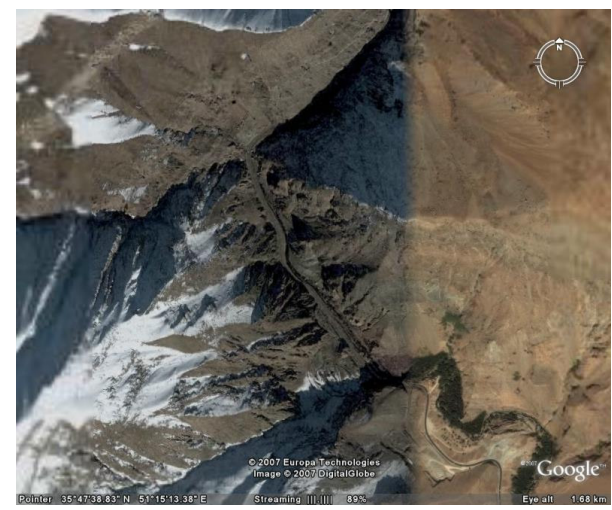

Fig. 1: Middle part of Soleghan road that steeper 20-35 degree, image obtains google earth 


\section{DISCUSS}

Necessary: Which ministry has the principal responsibility for road building and safety? Are all ministry departments constrained take account of the effects on the safety and natural environment of their actions, policies and decisions? As the principal environmental policy-maker in government, the ministry of Soleghan road in Iran has a wide range of interests. This area need to conservation, abandoned twisty, active fault, joint system aesthetic, structure, land use, landslide, catmint, channeling, cliffs, bedrock, break of slope, critical height, degradation, collapse, dumping, embankment, erosion management, development plan, drainage and road pattern(Fig. 2), grading, floods, land fills, joy land (at reset), surface materials, rivers that all of them (geomorphologic information) are related to road stability plans and policy-making and all there are in the area of geomorphology studies noticed by road policy-makers.

\section{Character of}

\section{A}

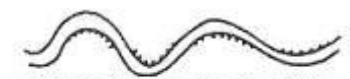

1 - Single Phase, Equiwidth channel

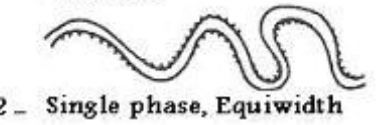
channel, Deep

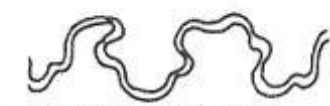

3- Two Phase, Bimodal B ankfull Sinuosity
Sinusity

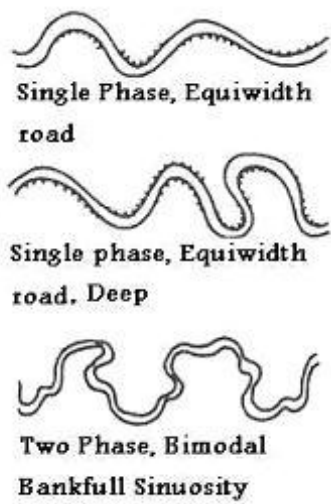

Fig. 2: pattern of river (A) Soleghan road pattern (b) and steep 1- low steep (10-25 degree), 2- middle steep (20-35 degree), 3- high steep (34-45 degree)

There are a special number of road safety issues in Soleghan road which geomorphologic information can make a direct and significant contribution. Amongst those must be particular interesting in Soleghan are river processes (Fig. 3), slope processes, joint and fault system how ever, slope processes are more important than river processes. Of cores, it doesn't mean than other geomorphologic process aren't important. Every road can include one or some important geomorphologic process. Iran and world road have various geomorphologic process, so some information is needed.
These subjects are common working for roadbuilders and road-policy makers and geomorphologies in Soleghan road as well as Iran and world.. The quality of common working responsibility concerned with the planning system of road, planner, managers and the development of land use ${ }^{[7]}$. Since, most development of road takes place on the surface or in the immediate subsurface (Fig. 4). So planning's and road policies are concerned with the interface which is the specialty of geomorphologies territory. Road Safety Inspection (RSI) can be the most important work geomorphologic now.

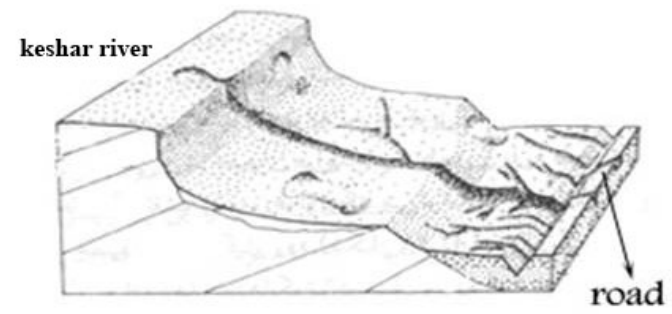

Fig. 3: channel effect of keshar on part of Soleghan road. Source: Moghimi, 2005

A

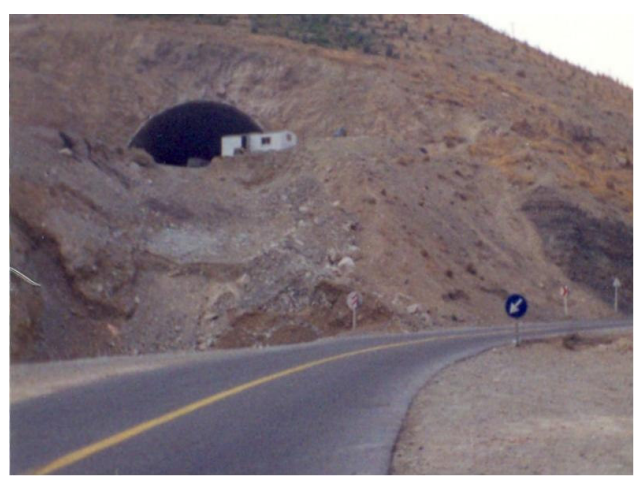

B

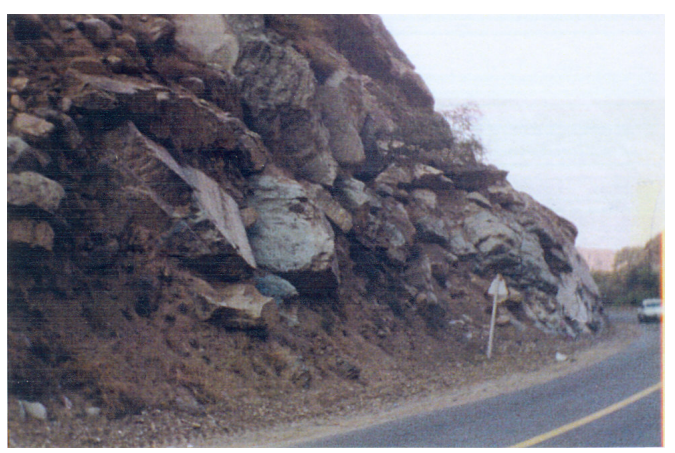

Fig. 4: Soleghan road A: tunnel No2 that building (october2006) B: part of road that slip threshold 
Am. J. Environ. Sci., 3 (4): 199-204, 2007

Table 1: Necessary information for Soleghsn road in view of slop process in order to safety

\begin{tabular}{|c|c|c|c|c|}
\hline & Feature & Cause of failure & Severity of unsafe & Information needed for analysis \\
\hline 1 & $\begin{array}{l}\text { Changes in road levels } \\
\text { and structure }\end{array}$ & Creep & $\begin{array}{l}\text { Variable slight if } \\
\text { movement is slow }\end{array}$ & Movement rates and amount \\
\hline 2 & $\begin{array}{l}\text { Increased required } \\
\text { maintenance of road }\end{array}$ & $\begin{array}{l}\text { Any tape or cause, site } \\
\text { specific }\end{array}$ & $\begin{array}{l}\text { Depends on magnitude of } \\
\text { slide }\end{array}$ & $\begin{array}{l}\text { Concern to cause of movement, } \\
\text { location of shear surface }\end{array}$ \\
\hline 3 & $\begin{array}{l}\text { Tension cracks parallel } \\
\text { to slope of road }\end{array}$ & $\begin{array}{c}\text { Rotational or block } \\
\text { failure, fault, potential } \\
\text { infinite joint, slope type of } \\
\text { sliding }\end{array}$ & $\begin{array}{l}\text { Failure imminent, severity } \\
\text { depend, on magnitude }\end{array}$ & $\begin{array}{l}\text { General slope condition, and } \\
\text { surface and subsurface profiled } \\
\text { of road }\end{array}$ \\
\hline 4 & $\begin{array}{c}\text { Tilted vertical features } \\
\text { of road }\end{array}$ & Creep & Low if movement is slow & $\begin{array}{c}\text { General material properties of } \\
\text { road }\end{array}$ \\
\hline 5 & $\begin{array}{l}\text { Misalignment of road, } \\
\text { fences or other linear } \\
\text { features of road }\end{array}$ & $\begin{array}{l}\text { Indicates relative slope } \\
\text { movement and nature of } \\
\text { misalignment }\end{array}$ & $\begin{array}{l}\text { Depends on magnitude of } \\
\text { misalignment }\end{array}$ & $\begin{array}{l}\text { Cause of movement, general } \\
\text { slope conditions }\end{array}$ \\
\hline 6 & Open joint rocks of road & $\begin{array}{l}\text { Potential rock falls due to } \\
\text { water, ice or weathering }\end{array}$ & Site-specific & $\begin{array}{l}\text { Susceptibility of rock to } \\
\text { weathering, joint patterns, } \\
\text { spacing and inclination }\end{array}$ \\
\hline 7 & $\begin{array}{c}\text { Presence of } \\
\text { escarpments in road }\end{array}$ & Rotational or block failure & $\begin{array}{c}\text { Depends on rock failure or } \\
\text { layer }\end{array}$ & General rock condition \\
\hline 8 & $\begin{array}{l}\text { Swampy of escarpments } \\
\text { in road }\end{array}$ & Poor draining & $\begin{array}{l}\text { Low to high, depending } \\
\text { on slope condition and } \\
\text { part of road }\end{array}$ & $\begin{array}{l}\text { surface location, soil profile an } \\
\text { permeability }\end{array}$ \\
\hline 9 & $\begin{array}{l}\text { Drainage features on } \\
\text { surface of road }\end{array}$ & $\begin{array}{c}\text { Erosion and solve material } \\
\text { of road }\end{array}$ & $\begin{array}{l}\text { May affect low area of } \\
\text { road surface }\end{array}$ & $\begin{array}{l}\text { Material tapes, source of water } \\
\text { and humidity }\end{array}$ \\
\hline 10 & $\begin{array}{l}\text { Isolated longitudinal } \\
\text { road bare of materials }\end{array}$ & $\begin{array}{c}\text { Avalanche, rockslide and } \\
\text { mudflow }\end{array}$ & $\begin{array}{l}\text { High, failure of adjacent } \\
\text { road may be possible }\end{array}$ & $\begin{array}{l}\text { General subsurface files, snow, } \\
\text { rock and material properties }\end{array}$ \\
\hline 11 & Single rock & Steep and separate of rock & High & Stability of single rock \\
\hline 12 & $\begin{array}{l}\text { Fresh rock on cliff } \\
\text { faces of road }\end{array}$ & weathering & $\begin{array}{l}\text { Very high depend on } \\
\text { magnitude of potential } \\
\text { failure }\end{array}$ & $\begin{array}{l}\text { Kind of rock, steep and cause } \\
\text { of weathering }\end{array}$ \\
\hline
\end{tabular}

Geomorphology Control System Development of Road (GCSDR): In Soleghan road, control system development of road building has not changed essentially since it has established. The fundamental requirement of the road building is that development not be undertaken without building permission ${ }^{[12]}$. It means that the all roads which are built (in Iran) have control system development and legislation. Permission results and plans and legal security in the Soleghan road are not observable. But road quality, their course and applications that have in the short-time, mid-time and long-time period, determine nature significantly. In this frame work to determine individual applications for road building studies must operate development control system of roads. It is many different nature, turbid and none planning of present roads in different areas in Iran and Soleghan road.

Though the effects of road building decisions may be long-lasting, and would cause demonstrable harm and hazards, each case must decided on its road development in order to structure morphologic of land and any other considerations as well as geomorphology control system development of road (GSCDR). The geomorphology control system development of road concerned to road building planning that those relating directly to the physical development and road safety and these relate to geomorphology.

The geomorphologic characteristics of length and width Soleghan road are largely depend on its material composition Land deep and on the processes affecting those materials both in the present day and during their evolution. So, the first geomorphologic question is that, which materials and processes there are in the Soleghan road.

At present time, the use of geomorphology information has of ten been implicit in the consideration given to such matters as length and width roads and landscapes in Soleghan conservation rather than being an explicit consideration.

It seems that, due to consideration may not have been given in all cases to the processes affecting that land use and landscape and the impact those processes could have on road development, or the ways in which road development might affect geomorphologic processes. In this view the Soleghan road is dividable to three part. Its south part has fluvial structure; section of fluvial sediments has Located under stone Levels and over terrace. The middle part has completely stone structure and have fault (Fig. 5), cross joints and fractured (Fig. 6), wrinkled and transferred. The north part of road includes Quaternary fluvial and shale stones. These three geomorphologic processes are limited in Soleghan road. 
As well as, the relatively common occurrence of road traffics related to geomorphologic phenomena, for example flooding, landslides, bridges denudation, fall that affecting development in area or being initiated by inappropriate engineering suggests that geomorphologic processes affecting land stability are not considered in some planning and geomorphologic control system development of road.

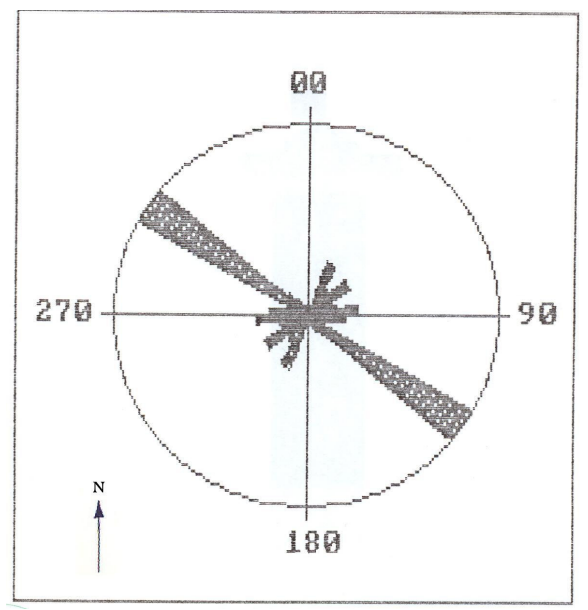

Fig. 5: fault system in Length of Soleghan road

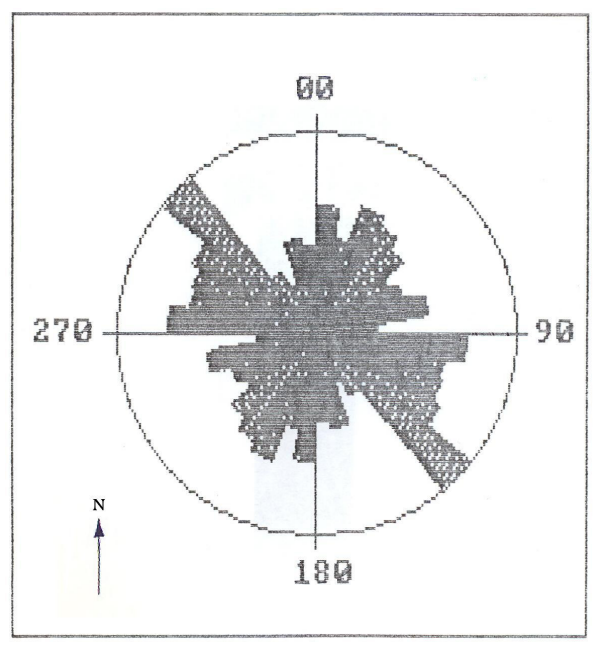

Fig. 6: Joint system in Length of Soleghan road

Slope Processes: Slope Processes in Soleghan road can have significant impacts on people, their properties, structures and communities for save and relief. Because of this and in pursuance of safety administration of the planning system, we must recognize our role in reviewing the scale and extent of problems arising from landslides and assessing the general applicability of methods and techniques developed at special sites in road. Research in slope processes followed a five-phase strategy:

1. Survey of the problem-to estimate the size, importance and geographical distribution of problems arising from slop processes in road areas [3];

2. Studies of causal mechanisms-to identify the factors that have contributed to the occurrence of slope processes and to make a preliminary assessment of their relative importance ${ }^{[3]}$. For soleghan road, joint factor, tectonic factor, climatic factor, rock and change slope is very important (table1).

3. Assessment of slope potential-to survey the potential or susceptibility of slopes for land sliding for the benefit of road users and developers ${ }^{[3,11]}$.

4. Prepare of actual strategies for slope stability.

5. Systemic planning for special save and relief in roads that have slope potential.

With the development of this five strategy, geomorphologic information has been able to contribute significantly to road building and safety policies, so that areas with potential for movement may be avoided or any necessary preventative or remedial actions may be taken in advance of construction. So, planners and road developers are also alerted at the earliest stage of any need for intensive site investigation, of the form that such investigation might take and of the broad cost implications of developing specific areas in Iran and world.

Elsewhere in Soleghan road of Iran, the problems arising from slope processes were not so clearly defined in terms of their significance. In priority areas where further work might be necessary, for example Chalos or Haraz roads in Iran. Thus recognized the need for comprehensive examinations of road slope processes and in Iran identify the scale and nature of them. Must notice that can identify over 7000 small and large landslides in mountain roads of Iran. Will also have climatic change in future that it will severely change the present geomorphology process in environment in world.

Important Reasons: There are six reasons for this apparent consideration of important eomorphologic factors, with emphasize Soleghan road:

The first, road planning and road building is concerned largely with the areas that where people live and work, that is where more development takes place, so, increase traffic (Fig. 7). However, road building will be counted as development factor. 
The second, the road events is increased ${ }^{[1]}$. Increasing and kind of road events show that part of them is due to no appropriate condition in road. The roads haven't necessary geomorphologic standards in different regions. The increasing damage and disaster of road cause that the road consider geomorphologic.

The third, in road building plans report that since have investigated (at least 10 report in Iran), haven't observe studies geomorphologic processes, but have consider to geology processes, of course consider geomorphology processes not effect for road building. Studding contemporary process as the most valuated geomorphologic subjects special sources capacity, stability, disasters evaluation, planning and rod building were after 1970, when over half of Iran road (as well as Soleghan road) and world road had built without using of this studding.

The fourth and perhaps more significant reason for geomorphologic processes not receiving their due consideration may lie in a gradual change in the nature and professional education of the building road. Many road-planners and road-builders not qualified initially in other discipline, especially geomorphology. In addition, don't have geomorphology course, and don't use of geomorphologies advisors (of course the geomorphology is a young science (at least in Iran)). In the world even during philosophies wondering of geomorphology in 1960s applied geomorphology special about roads that directly or related to process didn't appear in clear Landscape.

The fifth, those hazardous geomorphologic processes in Soleghan road are various. In this regard, wherever in Soleghan road that have been road building, can be related to one or more hazardous geomorphologic processes. At present vulnerability and denudation in hard caver of roads in north west(due to frizzing process and floods), effect of salt and floods in central and south road, and removability of wind dunes and floods in realm of roads in south east of Iran can decrease the road safety.

The sixth, reconstruction of road is very expensive, thus when consider it geomorphologic, its coast will be decrees.

It is thus important that, in order to maximize the use and consideration of geomorphologic information for road building and road safety, there must be communication between the providers of that information and road policies in area. In the $21_{\text {th }}$ century, in particular, this have been an important in the research program road building and policies in world.

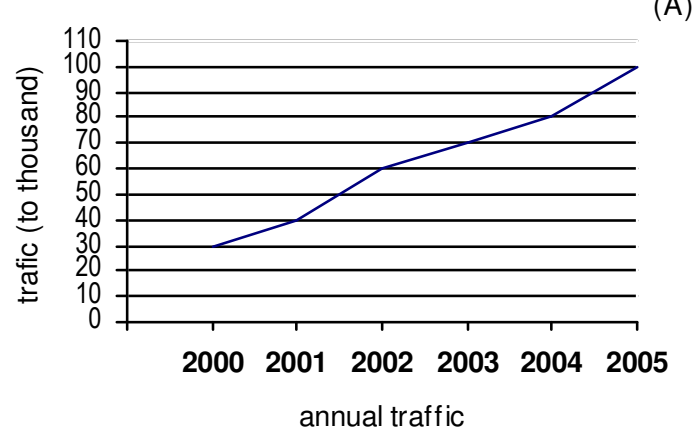

(B)

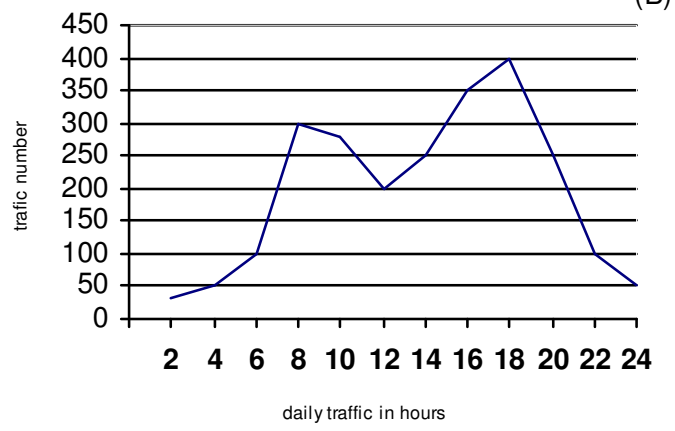

Fig. 7: Range of annual traffic (2000-2005), (A) and daily traffic base on average of 7 day (1-7 August 2002, (B) in Soleghan road، source: Moghimi, 2003, pp51-52.

In road building and safety cause of concern is the consideration given to geomorphology processes in the road planning system. Apart from a few isolated examples it is found that no one of the planning authorities gave adequate consideration to matters of slope stability in development plans and development control. A primary need is to increase awareness amongst planners, engineers, developers, insurers of road about the large mounts of geomorphology instability in road and of the little costs that it. International approach to roads safety in view of future geomorphology can be result of this subject that on the one hand geomorphology may be have an important part to achieve the more safety in roads, on the other hand many of roads in Iran and world haven't built by new geomorphologic information.

\section{CONCLUSION}

Geomorphologic information, alongside other road planning considerations and road policy-making can be an important element in road building, road safety and development control. In these regard, emphasizing on 
control system of road development, geomorphology processes and land stability with respect to kind of road and use.

In the Soleghan road, land stability, slope and river processes, joint and fault system and slope have significant importance. In Soleghan road where both ancient and present processes have significant effects on roads, there is a primary need for geomorphologic information. Relevant information must provided by geologists, hydrologists, soil scientists, and other as well as by geomorphologies. To achieve the full potential of studies and information the different specialists need to work together and to communicate to the potential users of their information, that is roadbuilder, road-guarder and road policy-makers, who will have varying levels of understanding.

Finally, road policy-makers and road builders shouldn't require their own geomorphologic needs information from non-specialists. Geomorphologies can not expect to know all needs information are required by roads planners and policy-makers, unless they are aware of how those plans are formulated and implemented. So, a two-way process of education and communication is required to needs since road hazards will be reduce and increase safety.

\section{ACKNOWLEDGMENTS}

This article is provided the survey proposal of 313/2/976 number grant in title geomorphologic specifications of slopes Soleghan road (from Zar to Soleghan), by protection of respectable search assistant of university of Tehran, Iran

\section{REFERENCES}

1. Eskandarian, A,2005, The government approach to improving vehide/highway transportation safety and its effectiveness, the papers first international conference on Traffic accidents (TAC), 21-22 December 2005, Mechanical Engineering Department, University of Tehran, Iran, pp1-23.
2. Chorley Richard,J.Stanley, A.schumm, David E,Sugden,1984, geomorphology, London, Methuen,pp1-17.

3. Conway,B.W; Aforster,K,J.Northmore and W.J.Barclay, 1983, South wales coalfield landslip survey, Institute geological sciences, Report NO EG80/4, and report No 83/6, pp110.

4. Cooke, R.U. and J.C.Doornkamp, 1990, Geomorphology in environmental management, Oxford, pp5-25.

5. Hooke J.M,1988, Geomorphology in Environmental Planing, John Wiley, pp105-120 and 247-262

6. Michael, A,Global 1993, Geomorphology, John Willey and Sons, New York.

7. Motamed,A and Moghimi,E, 2005 , Geomorphology and planning, SAMT, Tehran, Iran, p91-92

8. Moghimi,E, 2005, Geomorphologic specifications of slopes of Soleghan road (from Zar bridge to Soleghan), Geographical research Quarterly, No 78, ISSN 1019-7052, Mashhad, Iran, pp66-80.

9. Moghimi.E 2003, Geomorphological specifications of slopes in road Soleghan, University of Tehran, paper No 313/2/976, pp75.

10. Moghimi. E, 2005, Geomorphologic information need for road safety, policy-making and guarding in mountain areas, the paper first international conference on Traffic accidents (TAC), 21-22 December 2005, mechanical Engineering Department, University of Tehran, Iran, pp450.

11. Sir William Halcrow and Partners, 1986, assessment of Land slip potential-south Wales, Department of Environment.

12. Skabardonis Alexander, Mohammad Ashkan Sharafsaleh, California Path program: An over view, the paper first international conference on Traffic accidents (TAC), 21-22 December 2005, Mechanical Engineering Department, University of Tehran, Iran, pp74-78. 